\title{
Effect of Potentilla Fulgens L. on Selected Enzyme Activities and Altered Tissue Morphology in Diabetic Mice
}

\author{
Suktilang Majaw ${ }^{1}$ Sooni Kerki Challam ${ }^{1}$ Donkupar Syiem² \\ ${ }^{1}$ Department of Biotechnology \& Bioinformatics, North-Eastern Hill \\ University, Shillong, Meghalaya, India \\ 2 Department of Biochemistry, North-Eastern Hill University, Shillong, \\ Meghalaya, India \\ Address for correspondence Suktilang Majaw, PhD, Department of \\ Biotechnology \& Bioinformatics, North-Eastern Hill University, \\ Shillong, Meghalaya, 793022, India \\ (e-mail: smajaw.nehu@gmail.com; smajaw@nehu.ac.in).
}

J Morphol Sci 2018;35:153-160.

\begin{abstract}
Keywords

- amylase

- $\alpha$ - and $\beta$-glucosidase

- lipase

- Potentilla fulgens

- ultrastructural studies

Introduction The objective of the present study was to investigate the in vitro inhibitory effect of the Potentilla fulgens extract on amylase, $\alpha$ - and $\beta$-glucosidase, and lipase, as well as its effect on the ultrastructure of the liver, of the kidneys, and of the eye tissues in alloxan-induced diabetic mice. The present study was designed to get further insight regarding the action of $P$. fulgens from what has been previously known and reported about this plant.

Materials and Methods Roots of $P$. fulgens were extracted with 10 volumes of aqueousmethanol solution (1:4), and the prepared extract was used for in vitro inhibitory activity on amylase, $\alpha$-glucosidase, $\beta$-glucosidase, and lipase. Afterwards, the plant extract was intraperitoneally administered for alternated days ( $250 \mathrm{mg} / \mathrm{kg}$ body weight) to diabetic mice for 4 weeks, and an ultrastructural examination of the liver, the kidneys and the eye tissues was performed using a transmission electron microscope (JEM-100 CX II, Jeol Ltd., Tokyo Japan).

Results The $P$. fulgens extract showed inhibitory activity against all the four enzymes (amylase, $\alpha$ - and $\beta$-glucosidase, and lipase), with the highest percentage of inhibition $(94.57 \% \pm 0.16$ at $1 \mathrm{mg} / \mathrm{mL}$ ) being observed against $\alpha$-glucosidase when compared with the standard. The ultrastructural studies revealed a distortion in the structure of the nuclei and of the mitochondria in the kidneys and liver tissues of diabetic mice. Distortion of cell shape and disturbed orientation was observed in the eye lens of diabetic mice. The $P$. fulgens extract reversed/protected/reduced the ultrastructural alteration observed in the tissues (liver, kidney, and eye lens) of diabetic mice.

Conclusion The inhibitory effect of the $P$. fulgens extract against the aforementioned enzymes and its protective effect on the tissues of diabetic mice against alloxaninduced diabetes add further insight into the antidiabetic properties of this plant.
\end{abstract}

\section{Introduction}

Many medicinal plants have been reported to have multiple beneficial biological properties. Moringa oleifera, ${ }^{1}$ Phyllanthus amarus, ${ }^{2}$ Momordica charantia, ${ }^{3}$ Gymnema sylvestre, ${ }^{4}$ and
Grewia asiatica, ${ }^{5}$ to name a few, are medicinal plants with various pharmacological properties, including an antidiabetic property, which have been attributed to the presence of different bioactive compounds in them. Potentilla fulgens $\mathrm{L}$. is one of these medicinal plants known to possess various received

October 25, 2017

accepted

July 23, 2018

published online

October 2, 2018
DOI https://doi.org/

10.1055/s-0038-1669934. ISSN 2177-0298.
Copyright (c) 2018 by Thieme Revinter

Publicações Ltda, Rio de Janeiro, Brazil
License terms

() (1) $\Theta \circledast$ 
biological properties. It belongs to the Rosaceae family, commonly found in the Western Himalayas. Pharmacologically, the plant is reported to have hypoglycemic, ${ }^{6}$ antihyperglycemic, ${ }^{6}$ antitumor, ${ }^{7}$ antihypolipidemic, ${ }^{8}$ and antioxidant properties, ${ }^{9,10}$ as well as an antidiarrheal. ${ }^{11}$ It is a prophylactic agent, $^{12}$ with anthelmintic ${ }^{13}$ and wound healing properties, ${ }^{14}$ and even improves gum health. ${ }^{15}$ Qualitative and quantitative analysis of $P$. fulgens roots by nuclear magnetic resonance spectroscopy, matrix-assisted laser desorption/ionization with time-of-flight mass spectrometry (MS), electrospray ionization MS/MS and high-performance liquid chromatography/ultraviolet have also been reported. ${ }^{16}$ Phytochemical investigations of the root parts of $P$. fulgens have shown the presence of a novel bioflavonoid potifulgene along with epicatechin. ${ }^{17}$ It has also been reported that the aerial parts contain two new triterpenes, potentene- $A$ and potentene- $B$, as well as three known compounds, afzelchin- $4 \alpha \rightarrow 8^{\prime \prime}$ catechin, epiafzelechin, and rutin. ${ }^{15,18,19}$

Although the effect of the $P$. fulgens extract on different parameters $6,8,9,19-22$ under diabetic conditions has been reported previously, its inhibitory effect against amylase, $\beta$ glucosidase, and lipase under in vitro conditions has not been reported yet. Pancreatic $\alpha$-amylase and glucosidase are known to lower the level of postprandial hyperglycemia via the control of starch breakdown. ${ }^{23}$ The pancreatic lipase plays a key role in the efficient digestion of triglycerides, ${ }^{24}$ and is responsible for the hydrolysis of between 50 and $70 \%$ of the total dietary fats. ${ }^{25}$ Elevated triglyceride levels are a common dyslipidemic feature accompanying type 2 diabetes. ${ }^{26}$ Therefore, the inhibition of these digestive enzymes is a suitable target for the treatment of diabetes. Drugs that inhibit these enzymes are already available in the market, and are used for diabetes treatment. ${ }^{25,27}$ However, many of these synthetic hypoglycemic agents have their limitations, are non-specific, produce serious side effects, and fail to elevate diabetic complications. ${ }^{28}$ This opens an exciting opportunity for the development of new therapeutic drugs, especially from plant sources, which are considered safe. ${ }^{29}$ Therefore, in the present paper, the in vitro inhibitory effect of $P$. fulgens extract on the aforementioned enzymes was studied. Although $\alpha$-glucosidase inhibitory activity of $P$. fulgens has been reported previously by Kumar et al. $^{30}$, we have performed in vitro $\alpha$ glucosidase inhibitory activity of $P$. fulgens extract for comparison with its $\beta$-glucosidase inhibitory activity. In addition, the effect of the plant extract on the ultrastructure of the liver, of the kidneys, and of the eye lens tissues in diabetic mice was also investigated. Thus, the present study was designed to provide additional insights regarding the mechanism of action of this antidiabetic plant.

\section{Materials and Methods}

\section{Reagents}

Butylated hydroxyanisole, bathocuproine, copper nitrate, lecithin, lipase, potassium sodium tartarate, sodium acetate, sodium carbonate, sodium chloride, and triolein were purchased from Hi-Media Laboratories Pvt. Ltd. (Mumbai, Maharashtra, India). Acetic acid, $\alpha$-amylase, $\alpha$-glucosidase, $\beta$-glucosidase, dimethyl sulfoxide, dinitrosalicylic acid, dipotassium hydrogen phosphate, disodium hydrogen phosphate, glycine, n-heptane, methanol, p-nitrophenyl- $\alpha-D-$ glucopyranoside (pNDG), p-nitrophenyl- $\beta$-D-glucopyranoside, potassium dihydrogen phosphate, sodium dihydrogen phosphate, starch, sodium hydroxide, and triethanolamine were purchased from Sisco Research Laboratories Pvt. Ltd. (Mumbai, India). Alloxan and taurocholic acids were purchased from Sigma-Aldrich (St. Louis, Missouri, USA), acarbose (Glucobay 50) was purchased from Bayer Zydus Pharma (Thane, Maharashtra, India), and orlistat (Reeshape) was purchased from Meyer Organics Pvt. Ltd. (Thane, Maharashtra, India).

\section{Plant Material}

The roots of $P$. fulgens were collected from Bara bazaar, Shillong, Meghalaya, India (Voucher no: 464, North-Eastern Hill University [NEHU]). The collected plant materials were washed, shredded, dried and weighed. Afterwards, they were powdered, homogenized and extracted with an aqueous-methanolic solution (1:4). The mixture was filtered, and the filtrate was evaporated at $40^{\circ} \mathrm{C}$ using a rotary evaporator, (RE300, Stuart, Cole-Parmer, Beacon Road, Stone, Staffordshire, ST15 OSA, UK) and it was further lyophilized until it was totally dry. ${ }^{6,31}$ The obtained dried mass was used for the investigation.

\section{In vitro Enzyme Inhibitory Studies}

The evaluation of $\alpha$-amylase inhibition was determined by the method of Kim et al. ${ }^{32}$ The plant extract and acarbose (positive control) were prepared in a concentration range between 0.02 and $1.0 \mathrm{mg} / \mathrm{mL}$. A total of $50 \mu \mathrm{L}$ of plant extract/acarbose, $250 \mu \mathrm{L}$ of porcine pancreatic amylase $(1 \mathrm{mg} / 100 \mathrm{~mL})$, and $250 \mu \mathrm{L}$ of sodium phosphate buffer $(0.02 \mathrm{M}, \mathrm{pH} 6.9)$ were mixed and incubated at $37^{\circ} \mathrm{C}$ for 10 minutes, and $450 \mu \mathrm{L}$ of $0.5 \%$ starch solution was added to the reaction mixture and incubated at $37^{\circ}$ $\mathrm{C}$ for 20 minutes. The reaction was concluded by adding $500 \mu \mathrm{L}$ of 3,5-dinitrosalicylic acid, then heating at between 70 and $80^{\circ}$ $\mathrm{C}$ for 15 minutes, and centrifuging at $650 \mathrm{rpm}$ for 1 minute. The absorbance was measured at $\lambda 540 \mathrm{~nm}$.

The evaluation of $\alpha$-glucosidase inhibition was performed using pNDG as a substrate. ${ }^{32}$ A total of $50 \mu \mathrm{L}$ of plant extract/ acarbose $(0.02-1.0 \mathrm{mg} / \mathrm{mL})$ was mixed with $50 \mu \mathrm{L}$ of buffer and $50 \mu \mathrm{L}$ of $\alpha$-glucosidase solution ( $1 \mathrm{mg} / 100 \mathrm{~mL}$ ), followed by incubation at $37^{\circ} \mathrm{C}$ for 5 minutes. After the incubation period, $100 \mu \mathrm{L}$ of pNDG was added and incubated again at $37^{\circ}$ $\mathrm{C}$ for 15 minutes. The reaction was stopped by adding $750 \mu \mathrm{L}$ of sodium carbonate. The absorption of 4-nitrophenol was measured at $\lambda 400 \mathrm{~nm}$. Acarbose was used as a positive control.

The $\beta$-glucosidase assay was performed by adopting the method of Sánchez et al. ${ }^{33}$ with slight modification. A total of $100 \mu \mathrm{L}$ of p-nitrophenyl- $\beta$-D-glucopyranoside, $50 \mu \mathrm{L}$ of plant extract/acarbose $(0.02-1.0 \mathrm{mg} / \mathrm{ml})$, and $100 \mu \mathrm{L}$ of acetate buffer were mixed and incubated at $37^{\circ} \mathrm{C}$ for 10 minutes, followed by the addition of $50 \mu \mathrm{L}$ of $\beta$-glucosidase solution and incubation at $37^{\circ} \mathrm{C}$ for 30 minutes. After the incubation period, the reaction was stopped by adding $700 \mu \mathrm{L}$ of glycine- $\mathrm{NaOH}$ buffer. The absorbance was measured at $\lambda$ $410 \mathrm{~nm}$. Acarbose was used as a positive control. 
A method slightly modified from that of Lin et $\mathrm{al}^{34}$ was utilized to measure the pancreatic lipase inhibitory activity. A total of $50 \mu \mathrm{L}$ of pancreatic lipase, $100 \mu \mathrm{L}$ of substrate, and $100 \mu \mathrm{L}$ of plant extract/orlistat $(0.02-1.0 \mathrm{mg} / \mathrm{ml})$ were mixed and incubated at $37^{\circ} \mathrm{C}$ for 30 minutes, followed by the addition of $3 \mathrm{ml}$ of a chloroform, n-heptane and methanol mixture and centrifugation at 2,000 rpm for 10 minutes. One $\mathrm{ml}$ of copper reagent was added to the lower organic phase, followed by vigorous shaking for 10 minutes and centrifugation at 2,000 rpm for 10 minutes. One-half $\mathrm{ml}$ of supernatant was transferred to $0.5 \mathrm{ml}$ of chloroform containing $0.1 \%$ weight/ volume $(\mathrm{w} / \mathrm{v})$ of bathocuproine and $0.05 \% \mathrm{w} / \mathrm{v}$ of 3 -2-tertbutyl-4 hydroxylanisole. The absorbance was measured at $\lambda$ $480 \mathrm{~nm}$. Orlistat was used as a positive control.

The reaction mixture without the plant extract was used as a control, and the reaction mixture without the plant sample and the enzyme was used as a blank. The experiments were performed for five sets, and the data were represented as percentage of inhibition (mean \pm standard error of mean [SEM]). The percentage of inhibition of $\alpha$ amylase, $\alpha$-glucosidase, $\beta$-glucosidase, and lipase activities was calculated using the following formula:

Percentage of inhibition $=$

[Absorbance (control) - Absorbance (sample) $\times 100$ Absorbance (control)

\section{In vivo Studies}

\section{Animals and Experimental Designs}

Healthy, male Swiss albino mice, weighing between 25 and $30 \mathrm{~g}$, were used for the study. The mice were kept under controlled conditions, with the temperature maintained at $22^{\circ} \mathrm{C}$ on a 12 -hour light/dark cycle in the animal facility room of the NEHU. The mice were fed with balanced mice food obtained from Pranav Agro Industries Ltd. (New Delhi, India). The institutional guidelines were followed during the experimentation. The animal models were divided into three groups. The normal control group (group I) received only $2 \%$ ethanol intraperitoneally (ip); the diabetic control group (group II) received only $2 \%$ ethanol ip; and the $P$. fulgenstreated diabetic group (group III) received $250 \mathrm{mg} / \mathrm{kg}$ body weight (bw) of extract ip. After a period of 4 weeks, the mice were sacrificed, and the dissected tissues (liver, kidneys and eye lens) were studied using a JEOL100 CX II transmission electron microscope (JEM, JEOL Ltd., Tokyo, Japan).

\section{Preparation of Diabetic Mice}

The diabetic mice were administered ip with alloxan monohydrate prepared in acetate buffer, as described earlier. ${ }^{7}$ Prior to the administration, the mice fasted overnight but had ad libitum access to water. Mice with more than a threeto four-fold increase in their blood sugar levels were considered diabetic and used for further tests.

\section{Transmission Electron Microscopy Study}

The primary fixation of the isolated tissues of the liver, the kidney, and the eye lens from all the three groups were made in $3 \%$ glutaraldehyde prepared in a sodium phosphate buffer (200 mM; pH 7.4) for 3 hours at $4^{\circ} \mathrm{C}$. The materials were washed with the same buffer and postfixed in $1 \%$ osmium tetroxide and in a sodium phosphate buffer for 1 hour at $4^{\circ} \mathrm{C}$. The tissue samples were then washed with the same buffer for 3 hours at $4^{\circ} \mathrm{C}$, dehydrated in a graded ethanol series and then embedded in Araldite CY212 (Agar Scientific, Essex, UK) sections ranging between 60 and $90 \mathrm{~nm}$. The embedded tissues were cut on a RMC Ultramicrotome (Powertome-PC, RMC Boeckeler, USA) using a diamond knife (Ultra 45 degree, Diatome, USA) and the sections were mounted on a copper grid. Afterwards, the sections were stained with uranyl acetate and Reynolds lead citrate. The grids were examined using a JEOL100 CX II TEM at the Sophisticated Analytical Instrument Facility (SAIF), NEHU, Shillong, Meghalaya, India.

\section{Results and Discussion}

Diabetes, particularly type 2 , is a multifunctional disease. ${ }^{35}$ Therefore, a treatment with drugs that have multiple targets has great potential for tackling diabetes. ${ }^{36}$ Medicinal plants are known to contain a complex of phytochemicals and bioactivities that may have multiple benefits by targeting several metabolic pathways and, essentially, "killing several birds with one stone". ${ }^{3}$ Drugs with the ability to target more metabolic pathways seem to show more encouraging results than those that target a single pathway. ${ }^{37}$ The purpose of the present study was to explore the effect of $P$. fulgens root extract on multiple targets other than the known activities as an anti-diabetic plant. Here, the in vitro inhibitory effect of $P$. fulgens extract on $\alpha$-amylase, $\alpha$-glucosidase, $\beta$-glucosidase, and lipase were explored. In addition, its effect on the ultrastucture of the liver, of the kidney and of the eye lens was studied as no previous reports have been given on this study.

\section{In vitro Enzyme Inhibitory Studies}

The in vitro inhibitory activity of the $P$. fulgens extract against $\alpha$-amylase, $\alpha$-glucosidase, $\beta$-glucosidase, and lipase is shown in - Table 1. The maximum percentage of inhibition of $P$. fulgens against $\alpha$-amylase was found to be $37.51 \pm 0.750$ at $1 \mathrm{mg} / \mathrm{mL}$, which was lower than the inhibition percentage of $44.02 \pm 0.79$ at $1 \mathrm{mg} / \mathrm{ml}$ showed by the positive control. The percentage of inhibition of $P$. fulgens against $\alpha$-glucosidase was found to be maximum at $1 \mathrm{mg} / \mathrm{mL}(94.57 \pm 0.16)$, whereas that of the positive control was found to be $45.08 \pm 1.91$ at the same dose.

Thus, the $P$. fulgens extract showed an even higher inhibitory activity than the positive control at the same concentration. The highest percentage of inhibition of $\beta$ glucosidase by the $P$. fulgens extract was found to be $25.56 \pm 1.63$ at $0.6 \mathrm{mg} / \mathrm{mL}$, which was lower than that of the positive control. The maximum percentage of inhibition against lipase of $P$. fulgens and positive control was found to be $24.87 \pm 0.43$ and $24.31 \pm 0.75$ respectively, at the corresponding concentration of $1 \mathrm{mg} / \mathrm{mL}$. In the present study, the plant extract showed an inhibitory effect on all of the studied 
Table 1 Percentage (\%) of inhibition of Potentilla fulgens extract/positive control against $\alpha$-amylase, $\alpha$-glucosidase, $\beta$-glucosidase, and lipase

\begin{tabular}{|c|c|c|c|c|c|c|c|c|}
\hline \multirow{2}{*}{$\begin{array}{l}\text { Concentration } \\
(\mathrm{mg} / \mathrm{mL})\end{array}$} & \multicolumn{2}{|l|}{$\alpha$-amylase } & \multicolumn{2}{|l|}{$\alpha$-glucosidase } & \multicolumn{2}{|l|}{$\beta$-glucosidase } & \multicolumn{2}{|l|}{ Lipase } \\
\hline & $\begin{array}{l}\text { Positive } \\
\text { control (\%) }\end{array}$ & $\begin{array}{l}\text { Plant } \\
\text { extract (\%) }\end{array}$ & $\begin{array}{l}\text { Positive } \\
\text { control (\%) }\end{array}$ & $\begin{array}{l}\text { Plant } \\
\text { extract (\%) }\end{array}$ & $\begin{array}{l}\text { Positive } \\
\text { control (\%) }\end{array}$ & $\begin{array}{l}\text { Plant } \\
\text { extract (\%) }\end{array}$ & $\begin{array}{l}\text { Positive } \\
\text { control (\%) }\end{array}$ & $\begin{array}{l}\text { Plant } \\
\text { extract (\%) }\end{array}$ \\
\hline 0.02 & $15.58 \pm 1.81$ & $7.75 \pm 2.01$ & $12.11 \pm 1.03$ & $24.62 \pm 1.85$ & $16.55 \pm 1.38$ & $6.34 \pm 1.82$ & $10.68 \pm 1.30$ & $5.52 \pm 0.30$ \\
\hline 0.04 & $16.11 \pm 1.59$ & $14.95 \pm 2.86$ & $14.86 \pm 0.99$ & $27.56 \pm 1.87$ & $18.19 \pm 1.74$ & $8.73 \pm 1.22$ & $15.22 \pm 1.61$ & $8.27 \pm 0.33$ \\
\hline 0.06 & $16.98 \pm 1.12$ & $17.22 \pm 2.33$ & $16.21 \pm 1.51$ & $33.22 \pm 1.20$ & $20.09 \pm 1.42$ & $10.92 \pm 0.78$ & $16.31 \pm 1.43$ & $10.81 \pm 0.33$ \\
\hline 0.08 & $17.01 \pm 0.94$ & $19.77 \pm 2.41$ & $17.01 \pm 1.98$ & $38.68 \pm 1.49$ & $21.98 \pm 1.43$ & $13.22 \pm 1.07$ & $18.97 \pm 1.08$ & $13.60 \pm 0.32$ \\
\hline 0.1 & $17.55 \pm 1.08$ & $23.46 \pm 2.08$ & $18.85 \pm 2.01$ & $42.78 \pm 0.37$ & $22.12 \pm 1.74$ & $14.82 \pm 1.10$ & $20.70 \pm 1.03$ & $17.94 \pm 0.39$ \\
\hline 0.2 & $18.16 \pm 0.58$ & $26.70 \pm 0.89$ & $19.97 \pm 3.06$ & $65.11 \pm 0.55$ & $24.37 \pm 1.70$ & $16.44 \pm 0.58$ & $22.51 \pm 0.81$ & $21.24 \pm 0.52$ \\
\hline 0.4 & $24.56 \pm 0.80$ & $29.36 \pm 1.89$ & $26.54 \pm 2.88$ & $90.80 \pm 0.93$ & $30.14 \pm 1.52$ & $18.58 \pm 0.80$ & $24.31 \pm 0.75$ & $24.87 \pm 0.43$ \\
\hline 0.6 & $32.18 \pm 0.48$ & $33.59 \pm 0.92$ & $34.06 \pm 2.62$ & $93.38 \pm 0.88$ & $34.35 \pm 1.08$ & $25.56 \pm 1.63$ & $33.96 \pm 2.09$ & $14.30 \pm 0.71$ \\
\hline 0.8 & $39.44 \pm 0.48$ & $35.21 \pm 0.85$ & $39.16 \pm 2.20$ & $94.40 \pm 0.28$ & $40.20 \pm 1.30$ & $24.40 \pm 1.12$ & $41.78 \pm 1.58$ & $11.02 \pm 0.86$ \\
\hline 1.0 & $44.02 \pm 0.79$ & $37.51 \pm 0.75$ & $45.08 \pm 1.91$ & $94.57 \pm 0.16$ & $45.73 \pm 1.32$ & $23.06 \pm 1.72$ & $52.58 \pm 1.20$ & $7.37 \pm 0.99$ \\
\hline
\end{tabular}

Note: Values are represented as mean \pm standard error of mean where $n=5$.
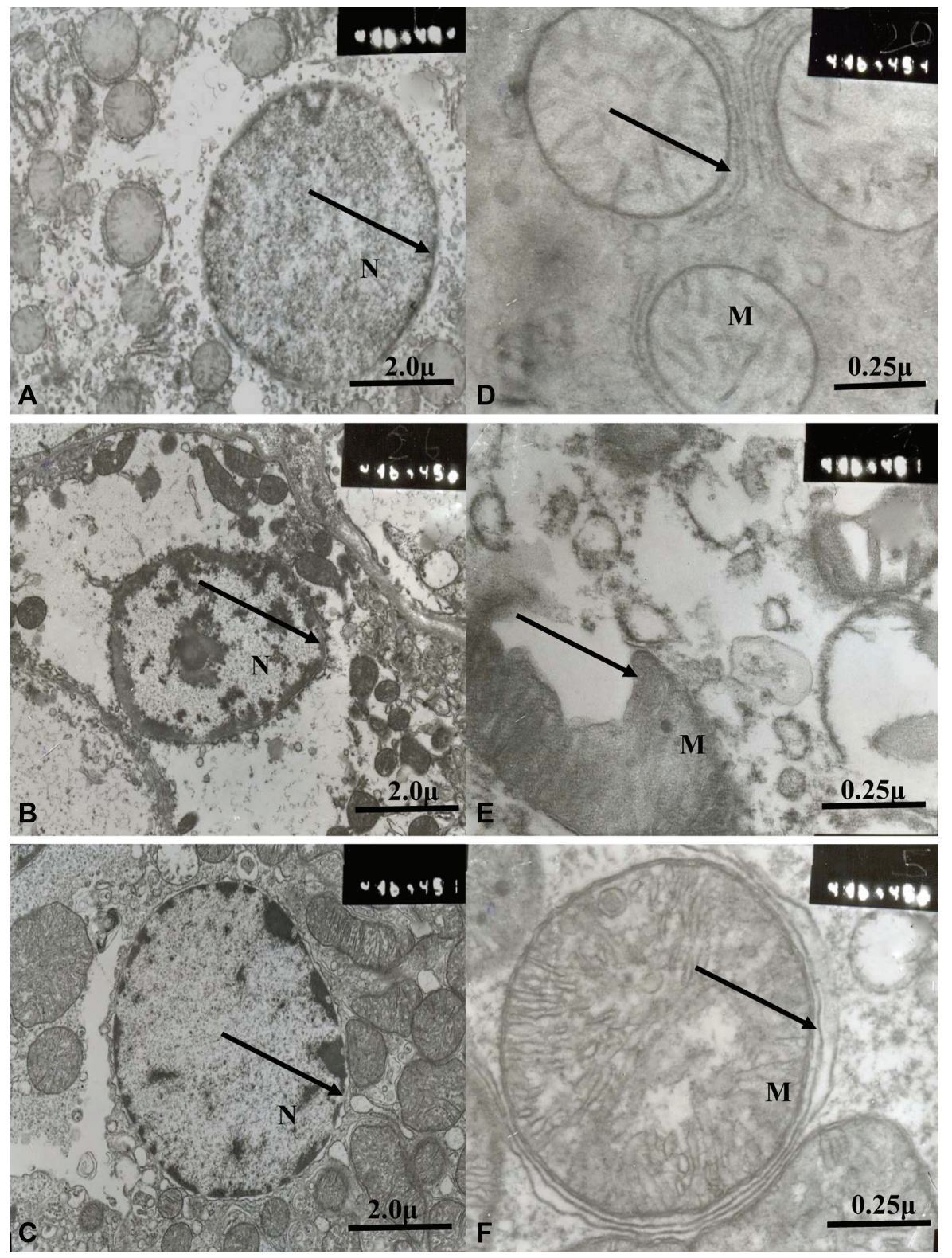

Fig. 1 Transmission electron micrograph showing the nuclei $(N)$ in the liver of normal mice $(A)$, diabetic mice (B), and Potentilla fulgens extracttreated diabetic mice at magnification x 5,000 (C). Transmission electron micrograph showing the mitochondria (M) in the liver of normal mice (D), diabetic mice (E), and P. fulgens extract-treated diabetic mice (F) at magnification $\times 40,000$. 
enzymes. However, the highest percentage of inhibition was shown against $\alpha$-glucosidase. This suggests that the P. fulgens extract may contain several inhibitory substances, thereby resulting in the inhibitions of these enzymes to different extents under the assay conditions used.

\section{In vivo Studies}

Marked differences were observed in the ultrastructural features of the nucleus and of the mitochondria in the liver and in the kidneys of diabetic mice compared with the normoglycemic mice, as shown in - Figs. 1-2. The nucleus is one of the most prominent cellular organelles, and its shape and size play an important role in cellular function. ${ }^{38}$ The normal liver and kidney cells revealed normal features of euchromatic nucleus (that is, with normal chromatin distribution), with fewer nuclear heterochromatic contents. The contours of the nuclei were round, with the nuclear membrane showing normal structures, such as regular outline and the absence of any prominent membrane protrusion or invagination (-Figs. 1A \& 2A). The mitochondria were wellmaintained in the form of typical oval and elliptic shapes, with smooth surfaces and clear outlines. The outer and inner mitochondrial membranes were intact, without breakage. The cristae were arranged in the form of a concentric ring or a vertical line, congested and clear. No abnormalities, such as membrane distortion or vacuolization, were observed in the mitochondrial matrix (-Figs. 1D \& 2D). The electron microscopic observations of the diabetic liver and kidney sections showed evagination and invagination of the nuclear envelope, as well as apoptotic cell nuclei with peripheral heterochromatin condensation and margination (-Figs. 1B \& 2B). This provides enough evidence that alloxan-induced diabetes is likely to cause apoptosis in liver and kidney cells, as previously reported. ${ }^{39,40}$ Hyperglycemia-mediated apoptosis has also been well-documented in several previous studies. ${ }^{41-43}$ The mitochondria are considered to be pivotal
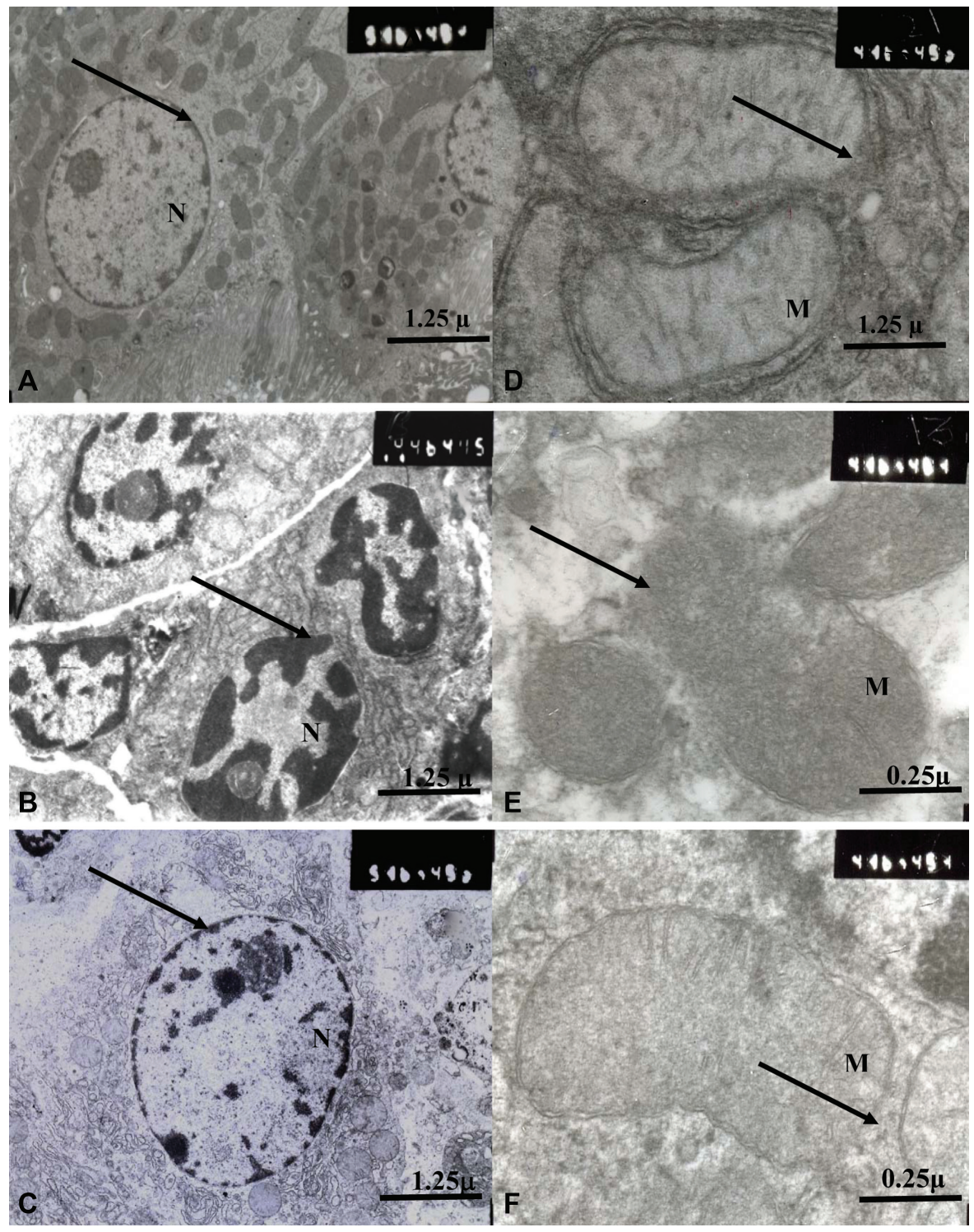

Fig. 2 Transmission electron micrograph showing the nuclei $(\mathrm{N})$ in the kidneys of normoglycemic mice (A), diabetic mice (B), and Potentilla fulgens extract-treated diabetic mice $(C)$ at magnification $\times 8,000$. Transmission electron micrograph showing the mitochondria (M) in the kidneys of normal mice (D), diabetic mice (E), and P. fulgens extract-treated diabetic mice (F) at magnification $x$ 40,000. 
organelles in determining cell destiny, and act as an 'on-off' switch, modulating autophagy and apoptosis in the process of cell death. ${ }^{44-46}$ In the present study, some mitochondria exhibited breakage of the outer membrane at places, while some showed distortion of the inner cristae in the liver and in the kidneys of diabetic mice (-Figs. 1E \& 2E), and these features have been reported in the pancreas of alloxaninduced diabetic mice. ${ }^{47}$ Apoptosis is widely assumed to involve the mitochondrial permeability transition pore complex (MPTPC), which opens a small inner-membrane pore that leads to the influx of water, ions, and small molecules, causing the mitochondrial matrix to swell and the outer membrane to rupture. ${ }^{48,49}$ Vacuolization is also observed in the liver and in the kidneys of diabetic mice, which indicates an autophagic cell death, morphologically characterized by an accumulation of vacuoles. ${ }^{50}$ Previous reports demonstrated that autophagy normally removes the aggregated or misfolded proteins induced by diabetes to defend against diabetes-induced mitochondria damage. ${ }^{51}$ The effect of the P. fulgens extract treatment was clearly visible, with an improvement in the ultrastructural features of the liver and of the kidney sections in diabetic mice, with a pronounced normalized appearance of the nuclei, as seen in the normal mice (-Figs. 1C \& 2C). The ultrastructural abnormalities observed in the mitochondria were improved in the treatment with the $P$. fulgens extract (-Figs. 1F \& $\mathbf{2 F}$ ). In previous reports, the $P$. fulgens extract has shown to normalize the lipid profile ${ }^{8}$ and the level of enzymes such as hexokinase, ${ }^{8}$ aldose reductase, ${ }^{19-21}$ sorbitol dehydrogenase, ${ }^{22}$ and the antioxidant enzymes ${ }^{9}$ in diabetic mice. This suggests the possible reason for its beneficial effect on the ultrastructural changes of the studied tissues observed in diabetic mice.

The lens of the eye is comprised of highly ordered fiber cells that are covered anteriorly by a monolayer of epithelial cells. Fiber cells are hexagonal in cross-section, and are arranged in a honeycomb-like pattern, forming an array of regularly aligned, concentric rings that comprise the bulk of the lens. ${ }^{52}$ The fiber lens are developed all around the lens equator, eventually meeting and forming end-to-end associations with corresponding fibers from other segments of the lens. Any disruption to this organization impairs light transmission and lens function, because a loose but intimate and regular bonding of lens fibers is essential for the normal functioning of the lens (-Fig. $\mathbf{3}$ ).

Mature lens fibers lack cellular organelles and contain a highly concentrated protein solution to enable light refraction. $^{53}$ The transmission electron micrograph of the cross sections of the lens revealed disorganized fiber patterns in diabetic mice, in which the arrangement of the fibers was distorted compared with that observed in the normal lens fibers. This is in line with previous reports that hyperglycemic states adversely affect the lens fiber and morphology patterns, resulting in structural alterations. ${ }^{54}$ In diabetic mice treated with the P. fulgens extract, a regular alignment of the lens fibers was observed. Although the lens segments were not as compact as observed in normal lenses, the honeycomb-like pattern with a regularly aligned array was
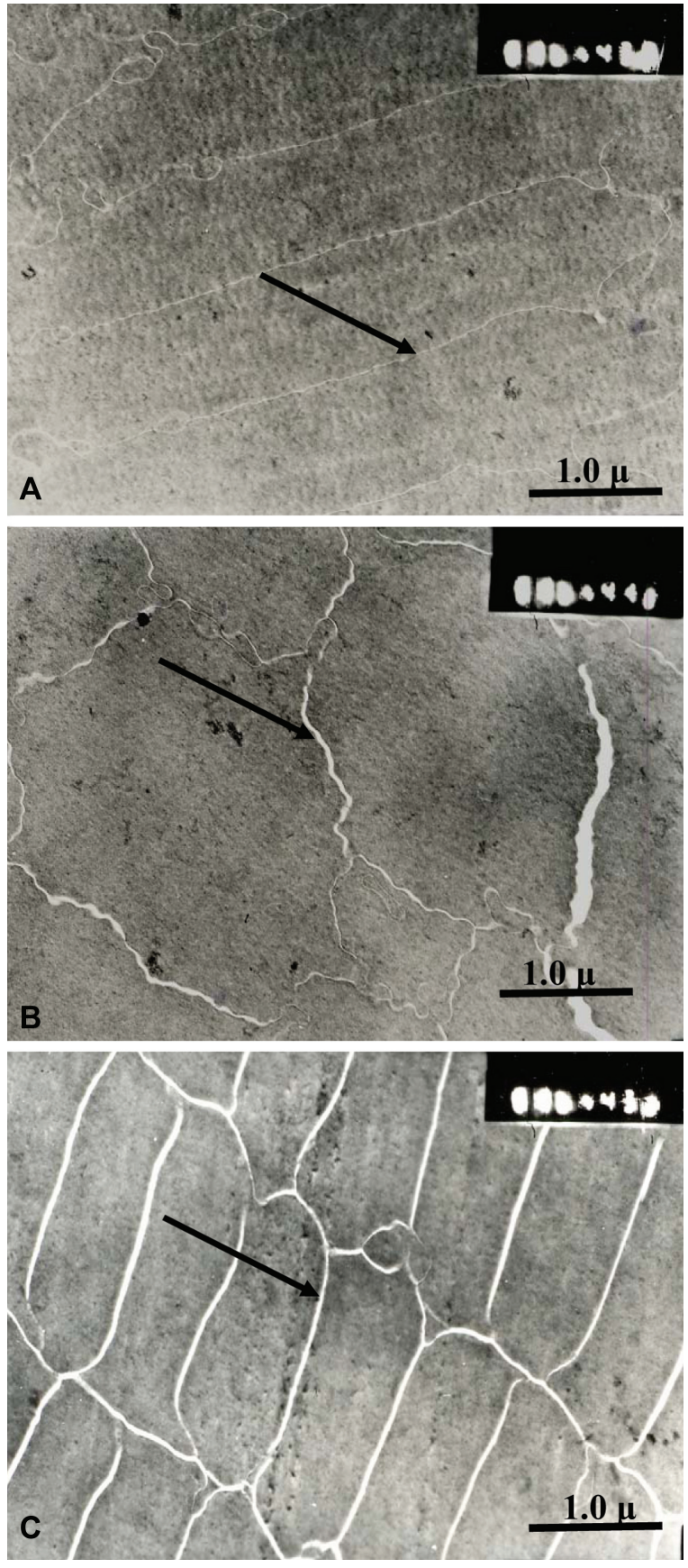

Fig. 3 Transmission electron micrograph showing the eye lens fibers of normoglycemic mice (A), diabetic mice (B), and Potentilla fulgens extract-treated diabetic mice $(C)$ at magnification $\times 10,000$.

seen to be regular, and the alterations in the fiber pattern were minimized in $P$. fulgens extract-treated diabetic mice. Many other plants are known for their ability to restore the alloxan-induced morphological damage in different organs. ${ }^{47,55}$

\section{Conclusion}

In conclusion, the experiment performed in the present study revealed that the $P$. fulgens root extract could inhibit enzymes such as amylase, $\alpha$-glucosidase, $\beta$-glucosidase, and 
lipase under in vitro conditions, and exhibit protective effects against the ultrastructural changes observed in the liver, in the kidney and in the eye lens of diabetic mice. Studying these effects has added new elements to the understanding of the antidiabetic property of this plant extract.

\section{Acknowledgments}

We would like to thank the DBT (Department of Biotechnology, Ministry of Science \& Technology, New Delhi) DSTFIST (Department of Science \& Technology- Fund for Improvement of S\&T Infrastructure, Ministry of Science \& Technology, New Delhi) Department of Biochemistry and the Department of Biotechnology \& Bioinformatics, NEHU, Shillong, India, for providing the basic necessary facilities and financial assistance. We would also like to thank the staff of the TEM instrument, SAIF, NEHU, Shillong, India, for their assistance in sample preparation and viewing.

\section{References}

1 Anwar F, Latif S, Ashraf M, Gilani AH. Moringa oleifera: a food plant with multiple medicinal uses. Phytother Res 2007;21(01): $17-25$

2 Verma S, Sharma H, Garg M. Phyllanthus amarus: A review. Journal of Pharmacognosy and Phytochemistry 2014;3(02):8-22

3 Gupta M, Sharma S, Gautam AK, Bhaduria R. Momordica charantia Linn (Karela): Nature's silent healer. Int J Pharm Sci Rev Res 2011; 11(01):32-37

4 Tiwari P, Mishra BN, Sangwan NS. Phytochemical and pharmacological properties of Gymnema sylvestre: an important medicinal plant. BioMed Res Int 2014;2014:830285

5 Zia-Ul-Haq M, Stanković MS, Rizwan K, Feo VD. Grewia asiatica L., a food plant with multiple uses. Molecules 2013;18(03):2663-2682

6 Syiem D, Syngai G, Khup PZ, Khongwir BS, Kharbuli B, Kayang H. Hypoglycemic effects of Potentilla fulgens $L$ in normal and alloxaninduced diabetic mice. J Ethnopharmacol 2002;83(1-2):55-61

7 Syiem D, Syngai C, Kharbuli B, Kayang H, Khongwir BS. Anti-tumor activity of crude root extract of Potentilla fulgens. Indian Drugs 2003; 40:124-125

8 Syiem D, Khup PZ, Syiem AB. Effects of Potentilla fulgens Linn. on carbohydrate and lipid profiles in diabetic mice. Pharmacologyonline 2009;2:787-795

9 Syiem D, Sharma R, Saio V. In vitro study of the antioxidant potential of some traditionally used medicinal plants of NorthEast India and assessment of their total phenolic content. Pharmacologyonline 2009;3:952-965

10 Saio V, Syiem D, Sharma R, Dkhar J. Amelioration of age-dependent increase in oxidative stress markers in male mice by extract of Potentilla fulgens. Redox Rep 2016;21(03):130-138

11 Tangpu V, Deori K, Yadav AK. Evaluation of safety and protective effects of Potentilla fulgens root extract in experimentally induced diarrhea in mice. J Intercult Ethnopharmacol 2014;3(03):103-108

12 Koparal M, Ïrtegün S, Alan H, Deveci E, Gülsün B, Seker U. Effects of Potentilla fulgens as a prophylactic agent in tibial defects in rats. Anal Quant Cytopathol Histpathol 2016;38(02):111-116

13 Roy B, Swargiary A, Syiem D, Tandon V. Potentilla fulgens (Family Rosaceae), a medicinal plant of north-east India: a natural anthelmintic? J Parasit Dis 2010;34(02):83-88

14 Kundu A, Ghosh A, Singh NK, et al. Wound healing activity of the ethanol root extract and polyphenolic rich fraction from Potentilla fulgens. Pharm Biol 2016;54(11):2383-2393

15 Kaul K, Jaitak V, Kaul VK. Review on pharmaceutical properties and conservation measures of Potentilla fulgens Wall. ex Hook. - A medicinal endangered herb of higher Himalaya. Indian J Nat Prod Resour 2011;2(03):298-306

16 Choudhary A, Radhika M, Chatterjee A, Banerjee UC, Singh IP. Qualitative and quantitative analysis of Potentilla fulgens roots by NMR, matrix-assisted laser desorption/ionisation with time-offlight MS, electrospray ionisation MS/MS and HPLC/UV. Phytochem Anal 2015;26(02):161-170

17 Jaitak V, Kaul VK, Himlata, et al. New hopane triterpenes and antioxidant constituents from Potentilla fulgens. Nat Prod Commun 2010;5(10):1561-1566

18 Jaitak V, Sharma K, Kalia K, et al. Antioxidant activity of Potentilla fulgens: An alpine plant of western Himalaya. J Food Compos Anal 2010;23(02):142-147

19 Syiem D, Majaw S. Effect of Potentilla fulgens L. aldose reductase activity of normal and diabetic mice. Inventi Rapid: Ethnopharmacology 2010;1(01):13

20 Majaw S, Syiem D. In vitro aldose reductase inhibitory potential of fractions isolated from Potentilla fulgens roots. J Appl Pharm Sci 2016;6(08):102-109

21 Syiem D, Majaw S. Effect of different solvent extracts of Potentilla fulgens L. on aldose reductase and sorbitol dehydrogenase in normoglycemic and diabetic mice. Pharmacologyonline 2011; 3:63-72

22 Syiem D, Majaw S. Effect of Potentilla fulgens L. methanolic extract on sorbitol dehydrogenase in normal and alloxan-induced diabetic mice. Pharmacologyonline 2010;2:671-680

23 Kajaria D, Ranjana, Tripathi J, Tripathi YB, Tiwari S. In-vitro $\alpha$ amylase and glycosidase inhibitory effect of ethanolic extract of antiasthmatic drug - Shirishadi. J Adv Pharm Technol Res 2013;4 (04):206-209

24 Lowe ME. The triglyceride lipases of the pancreas. J Lipid Res 2002;43(12):2007-2016

25 Birari RB, Bhutani KK. Pancreatic lipase inhibitors from natural sources: unexplored potential. Drug Discov Today 2007;12(1920):879-889

26 Ginsberg HN, Zhang YL, Hernandez-Ono A. Regulation of plasma triglycerides in insulin resistance and diabetes. Arch Med Res 2005;36(03):232-240

27 PS, Zinjarde SS, Bhargava SY, Kumar AR. Potent $\alpha$-amylase inhibitory activity of Indian Ayurvedic medicinal plants. BMC Complement Altern Med 2011;11:5

28 Cheng AY, Fantus IG. Oral antihyperglycemic therapy for type 2 diabetes mellitus. CMAJ 2005;172(02):213-226

29 Tiwari S. Plants: A rich source of herbal medicine. Journal of Natural Products 2008;1:27-35

30 Kumar D, Ghosh R, Pal BC. $\alpha$-glucosidase inhibitory terpenoids from Potentilla fulgens and their quantitative estimation by validated HPLC method. J Funct Foods 2013;5:1135-1141

31 Harborne JB. Phytochemical methods. London and New York: Chapman and Hall; 1998

32 Kim JS, Hyun TK, Kim MJ. The inhibitory effects of ethanol extracts from sorghum, foxtail millet and proso millet on $\alpha$-glucosidase and $\alpha$-amylase activities. Food Chem 2011;124(04):1647-1651

33 Sánchez-Medina A, García-Sosa K, May-Pat F, Peña-Rodríguez LM. Evaluation of biological activity of crude extracts from plants used in Yucatecan traditional medicine part I. Antioxidant, antimicrobial and beta-glucosidase inhibition activities. Phytomedicine 2001;8(02):144-151

34 Lin X, Xu B, Rui L. Pancreatic lipase inhibitory effects of mangosteen pericarps. Advance Journal of Food Science and Technology 2014;6(03):284-291

35 Ahmed D, Kumar V, Verma A, Shukla GS, Sharma M. Antidiabetic, antioxidant, antihyperlipidemic effect of extract of Euryale ferox salisb. with enhanced histopathology of pancreas, liver and kidney in streptozotocin induced diabetic rats. Springerplus 2015;4:315

36 Varghese Z, Moorhead JF, Ruan XZ. The PPARalpha ligand fenofibrate: meeting multiple targets in diabetic nephropathy. Kidney Int 2006;69(09):1490-1491 
37 Chang CLT, Lin Y, Bartolome AP, Chen YC, Chiu SC, Yang WC. Herbal therapies for type 2 diabetes mellitus: chemistry, biology, and potential application of selected plants and compounds. Evid Based Complement Alternat Med 2013;2013:378657

38 Webster M, Witkin KL, Cohen-Fix O. Sizing up the nucleus: nuclear shape, size and nuclear-envelope assembly. J Cell Sci 2009;122(Pt 10):1477-1486

39 Rashid K, Das J, Sil PC, et al. Taurine ameliorate alloxan induced oxidative stress and intrinsic apoptotic pathway in the hepatic tissue of diabetic rats. Food ChemToxicol 2013;51:317-329

40 Das J, Sil PC. Taurine ameliorates alloxan-induced diabetic renal injury, oxidative stress-related signalling pathways and apoptosis in rats. Amino acids 2012;43(04):1509-1523

41 Cai L, Li W, Wang G, Guo L, Jiang Y, Kang YJ. Hyperglycemiainduced apoptosis in mouse myocardium: mitochondrial cytochrome C-mediated caspase-3 activation pathway. Diabetes 2002; 51(06):1938-1948

42 Moley KH, Chi MM, Knudson CM, Korsmeyer SJ, Mueckler MM. Hyperglycemia induces apoptosis in pre-implantation embryos through cell death effector pathways. Nat Med 1998;4(12): 1421-1424

43 Moley KH. Hyperglycemia and apoptosis: mechanisms for congenital malformations and pregnancy loss in diabetic women. Trends Endocrinol Metab 2001;12(02):78-82

44 Lemasters JJ, Nieminen AL, Qian T, et al. The mitochondrial permeability transition in cell death: a common mechanism in necrosis, apoptosis and autophagy. Biochim Biophys Acta 1998; 1366(1-2):177-196

45 Rodriguez-Enriquez S, He L, Lemasters JJ. Role of mitochondrial permeability transition pores in mitochondrial autophagy. Int J Biochem Cell Biol 2004;36(12):2463-2472
46 Stoka V, Turk B, Schendel SL, et al. Lysosomal protease pathways to apoptosis. Cleavage of bid, not pro-caspases, is the most likely route. J Biol Chem 2001;276(05):3149-3157

47 Walvekar MV, Pol SB, Chandrasekhar Sagar BK. Histopathological and ultrastructural studies of the effect of fenugreek seed extract on pancreas of alloxan induced diabetic mice. Int J Pharmaceutical Sciences and Research 2014;5(07):2960-2965

48 Kinnally KW, Peixoto PM, Ryu SY, Dejean LM. Is mPTP the gatekeeper for necrosis, apoptosis, or both? Biochim Biophys Acta 2011;1813(04):616-622

49 Kroemer G, Galluzzi L, Brenner C. Mitochondrial membrane permeabilization in cell death. Physiol Rev 2007;87(01):99-163

50 González-Polo RA, Boya P, Pauleau AL, et al. The apoptosis/ autophagy paradox: autophagic vacuolization before apoptotic death. J Cell Sci 2005;118(Pt 14):3091-3102

51 Kaniuk NA, Kiraly M, Bates H, Vranic M, Volchuk A, Brumell JH. Ubiquitinated-protein aggregates form in pancreatic beta-cells during diabetes-induced oxidative stress and are regulated by autophagy. Diabetes 2007;56(04):930-939

52 Sugiyama Y, Lovicu FJ, McAvoy JW. Planar cell polarity in the mammalian eye lens. Organogenesis 2011;7(03):191-201

53 Heys KR, Cram SL, Truscott RJW. Massive increase in the stiffness of the human lens nucleus with age: the basis for presbyopia? Mol Vis 2004;10:956-963

54 Joy A, Currie MS, Donohue ST, Al-Ghoul KJ. Aberrant basal fiber end migration underlies structural malformations in a streptozotocin-induced diabetic rat model. Exp Eye Res 2009;89(03): 344-357

55 Ragawan B, Krishnakumari S. Effect of T. arjuna stem bark extract on histopathology of liver, kidney and pancreas of alloxaninduced diabetic rats. Asian J Biomed Res 2006;9:189-197

Erratum: The category of DOI: 10.1055/s-0038-1669934 has been changed from Review Article to Original Article. 